\title{
Virulence of Local isolates of Entomopathogenic Fungi on the common agricultural pest Spodopteralitura (Fabricius) Lepidoptera:Noctuidae
}

\author{
K. N. P. Chandra Teja ${ }^{1,2}$ and S. J. Rahman ${ }^{1 *}$ \\ ${ }^{1}$ AICRP on Biological control of Crop Pests, PJTSAU, \\ Rajendranagar, Hyderabad, India \\ ${ }^{2}$ Centre for Environment, Institute of Science and Technology, JNTUH, \\ Kukatpally, Hyderabad, India \\ *Corresponding author
}

K e y w o r d s
Entomopathogenic
fungi,
Metarhiziuman
isopliae,
Lecanicillium
lecanii,
Spodoptera litura,
bioassay
Article Info
Accepted:
20 January 2020
Available Online:
10 February 2020

Keywords

Entomopathogenic fungi,

Metarhiziuman

isopliae

lecanii,

Spodoptera litura,

bioassay

Article Info

Accepted:

Available Online:

\section{A B S T R A C T}

The polyphagous insect pest Spodoptera litura is known to cause huge losses to agriculture all over the world. Its increasing resistance to chemical insecticides necessitates the use of biological options such as Entomopathogenic fungi. Strains of Entomopathogenic fungi, Beauveria bassiana, Metarhizium anisopliae and Lecanicillium lecanii are known to control the incidence of the pest. Laboratory bioassay was conducted to evaluate the effect of different local isolates of $M$. anisopliae and L. lecanii on the growth and development of S. litura. Results indicate that the susceptibility of the insect pest depends on various factors like the fungal isolate, dosage of the infective propagule, age of the insect larvae and the developmental stage tested. Among the isolates studied, M. anisopliae isolate $\mathrm{PaCo} 4$ was found to be most virulent on S. litura neonates and the isolate $\mathrm{ArCo} 3$, the least virulent. In a subsequent study on the $3^{\text {rd }}$ instar larvae of insect pest, the isolates were found to prolong the larval duration, lower the pupation but the pupal period remained unchanged. A lowered adult emergence and longevity was also observed. Further study of the field efficacy of the Entomopathogenic fungal isolates are needed so that they can be successfully used for controlling the pest on the field.

\section{Introduction}

Spodoptera litura Fabricius (Lepidoptera: Noctuidae) is a polyphagous chewing insect pest of subtropical and tropical agricultural crops causing heavy losses to the farmers (Brown and Dewhurst 1975; Holloway and Jeremy, 1989). It is widely distributed throughout the world (Anand et al., 2009) and has been reported from nearly 120 food crops all over the world of which 40 are grown in India. Indiscriminate and non-judicious use of insecticides to control the pest has resulted in the development of resistance to as many as 20 different active ingredients of insecticides (Armes et al., 1997) besides the loss of 
natural enemies of the pest. Hence, there is a need to explore ecologically sustainable options to control this devastating pest.

One such option is the use of biological control involving the use of natural enemies like predators, parasitic wasps and flies as well as pathogens like Bacteria, fungi and viruses to suppress the pest. Myco-biocontrol strategies involve the environmentally sound and effective use of a group of fungi termed Entomopathogenic fungi (EPF) in mitigating insect pests.

EPFs are a large polyphyletic group of insect pathogens mainly from the orders of Entomophthorales and Hypocreales. Only few genera among them are well characterized with respect to their pathogenicity to different insects and thus are of agricultural importance. Some are been used commercially as biological control agents worldwide (de Faria and Wraight, 2007).

The mode of entry of the fungal pathogen into the insect body is either by ingestion or by contact of the fungal conidia with the host cuticle. Upon adhesion of the cuticle surface, the conidia of the Entomopathogenic fungi germinate and the germ tubes penetrate the cuticle and the epidermal layers by the consorted action of mechanical pressure and secretion of enzymes like proteases, chitinases, and lipases (Cho et al., 2006b).

In the Haemocoel of the insect, the fungus proliferates into yeast like hyphal bodies called Blastospores. Death of the insect is the result of starvation or physiological /biochemical disruption brought about by the fungus (Feng et al., 1994).

Virulent strains produce toxic proteins such as cyclic peptides, cyclosporins and dextrusins which are known to enhance the virulence of the pathogen. Fungal mycelia eventually emerge from the cuticle of the dead cadaver of the insect and produce conidiophores. However, under suitable humidity conditions, aerial conidia are formed externally dead insect aiding the spread the fungus.

Metarhizium anisopliae was first isolated near Odessa, Ukraine from infected larvae of the wheat cockchafer Anisopliae austriaca in 1879 and was initially named Entomphthora anisopliae. It causes green muscardine disease and is pathogenic to a large number of insect species, many of which are agricultural and forest insects (Ferron, 1978).

It was the first known fungus to be used for bio control of an insect pest in 1888 and represents about 33.9 percent of the total Myco insecticides developed for Biological control use (de Faria and Wraight, 2007).

Lecanicillium lecanii is a Deuteuromycete (imperfect) fungal species widely distributed in warm and humid environments (Nunez et al., 2008). It was first observed by Zimmermann in 1898 on Lecanium viride on coffee in Indonesia. L. lecanii is proven to be very effective against scale insects like Aphids, whiteflies (Wang et al., 2007; Van et al., 2007) and Thrips (Vestergaard et al., 1995). Few strains of L. lecanii are also found to be effective against some plant pathogenic fungi (Askary et al., 1998; Alavo, 2015) and Nematodes (Shinya et al., 2008) also.

In the present study, local strains of Entomopathogenic fungi isolated from different crop rhizospheres of the semi-arid region of Andhra Pradesh and Telangana were tested for their virulence against the polyphagous agricultural pest Spodoptera litura in a laboratory bioassay.

\section{Materials and Methods}

\section{Preparation of conidial suspensions of the fungal isolates}

A total of seven fungal isolates were tested in 
a laboratory bioassay for their virulence against the pest Spodoptera litura. Five isolates were isolated from different crop rhizospheres of Telangana and Andhra Pradesh using semi selective medium and were morphologically identified as Metarhizium and Lecanicillium spp using standard identification key. Later molecular characterization of the ITS region of the isolates using specific primers (White et al., 1990) identified three isolates among them, KoGn5, LaMa1 and PaCo4 as Metarhizium anisopliae (Chandra teja and Rahman, 2016) and two isolates, $\mathrm{ArCo} 3$ and $\mathrm{PRg} 4$ as Aphanoas custerreus.

One strain each of Metarhiziuman isopliae and Lecanicillium lecanii i.e., MaAICRP and LlAICRP were obtained from the All India Coordinated Research Programme (AICRP) on Biological control of Crop Pests and Weeds, Hyderabad. Sterile Tween 80 solution $(0.02 \%)$ was poured on 15 day old culture plates of the fungi. The mycelia and conidia were scrapped using a sterile spatula and taken in a conical flask. The suspension was passed through double layered muslin cloth to obtain a conidial suspension free of mycelial fragments and media. The concentration of suspension was determined using a haemocytometer and further serially diluted to obtain spore suspension of concentration $3.2 \mathrm{x}$ $10^{8}, 10^{7}, 10^{6}$ and $10^{5} / \mathrm{ml}$

\section{Rearing of Spodoptera litura insect culture}

Eggs of Spodoptera litura (accession number: NBAII-MP-NOC-02: S.litura) were obtained from the insect rearing facility of The National Bureau of Agricultural Insect Resources (NBAIR), Bengaluru. The emerging neonate larvae were fed on tender castor leaves. To maintain the turgidity of the leaves the cut ends of the petiole were kept in moist cotton.
All the instars of the larvae were cultured in plastic trays covered with muslin cloth for aeration. The trays were cleaned daily and the fresh feed was added. The pupae were separated into a glass jars filled with sterile sand till one inch from the bottom. The jars were covered with black paper to maintain dark conditions. The emerging adult moths were transferred to glass jars of size 15 X 20 $\mathrm{cm}$ covered with muslin cloth. Around twenty adult moths were kept per jar to maintain the optimum sex ratio. The adults were fed with $10 \%$ honey solution. Folded cheese paper was placed in the jars to facilitate laying of egg masses. The egg masses laid were transferred to petriplates lined with moistened filter paper and kept at $28 \pm 2^{\circ} \mathrm{Cfor}$ hatching. Uniform sized $3^{\text {rd }}$ instar larvae were usedin the Bioassay study.

\section{Insect Bioassays}

The virulence of the Entomopathogenic fungal isolates on the larvae, pupae and adults of the S. litura was tested using leaf dip assay method. Tender castor leaves used for the bioassay were first cleaned with running tap water to remove dirt particles \& other contaminants and air-dried. Leaves were dipped in fungal spore suspension for $30 \mathrm{sec}$ and air dried in a laminar air flow hood. Single leaf was placed in a perforated plastic container of the size $9 \mathrm{~cm}$ diameter and $9 \mathrm{~cm}$ height. Ten larvae per container were released on the leaf for feeding. Five replications were maintained for each of the seven fungal isolates and four conidial concentrations. A negative control was maintained with $0.02 \%$ sterile Tween $80^{\circledR}$ in sterile distilled water. The mortality of the larvae was recorded first on the second day after treatment and from then on daily till the seventh day after treatment.For the effect on the different developmental stages of the insect, observations were recorded till the death of the adults. Feeding was changed daily from 
second day with fresh untreated castor leaves. Mortality in the treatments was corrected by removing the natural mortality in the control (Abbott, 1925) and arcsine transformed to normalize the data before the analysis of variance (ANOVA).

\section{Results and Discussion}

\section{Virulence ofthe Fungal isolates at different conidial concentrations}

The fungal isolates were evaluated for their Mortality of Spodoptera litura larvae at four different conidial concentrations. Three day old larvae were fed on castor leaves treated with conidial suspensions of four different concentrations $\left(3.2 \times 10^{5}, 10^{6}, 10^{7}\right.$ and $10^{8}$ conidia/ml) and the effect of the isolate as well as the conidial concentration on the mortality of the larvae was evaluated after 48 hrs till the seventh day from the treatment.

The results indicated a variation in the susceptibility of the $S$. litura larvae to isolates studied(Table-1). Significant variation in mortality of the insect pest at different conidial concentrations was also noted for few isolates. The mortality caused by the isolates ranged from $10.82 \%$ for $\mathrm{ArCo} 3$ at $10^{5} / \mathrm{ml}$ to $63.73 \%$ for $\mathrm{PaCo} 4$ at $10^{8} / \mathrm{ml}$. An increase in the mortality was observed with the increase in concentration of the conidial suspension from $10^{5}$ to $10^{8}$ conidia/ml. However, for the L. lecanii isolate LlAICRP and A. terreus isolate $\mathrm{ArCo} 3$, there was no significant increase in the mortality percentages from the lowest to the highest conidial concentration studied. Among them, $M$. anisopliae isolate $\mathrm{PaCo} 4$ showed the highest mortality at concentrations $10^{5}$ and $10^{8}$ conidia/ml and KoGn5 showed the highest mortality at $10^{6}$ and $10^{7}$ conidia/ml concentrations. The isolate $\mathrm{PaCo} 4$ is the most virulent of all the isolates as its mortality percentage was higher than the others at the lowest conidial concentration studied. However, M. anisopliae isolate MaAICRP showed second highest mortality $(27.89 \%)$ at $10^{5}$ conidia/ml concentration which was same with that shown by the most virulent isolate (PaCo4). Of the A. terreus isolates, PRg4 at $10^{8} / \mathrm{ml}$ conidial concentration showed mortality of $S$ litura larvae equal to that of the M. anisopliae isolate MaAICRP (48.51\%). However, isolate $\mathrm{ArCo} 3$ showed the least virulence of all the isolates.

In terms of the least concentration for $50 \%$ mortality (LC50), M. anisopliae isolates KoGn5 and PaCo4 had the least LC50 (3 x $10^{6}$ conidia/ml $)$ at followed by LaMa1 $(1 \mathrm{x}$ $10^{7}$ conidia/ml) and MaAICRP (4 x $10^{7}$ conidia/ml). The highest LC50 was observed for A. terreus isolate $\mathrm{ArCo} 3$ at $7 \times 10^{14} / \mathrm{ml}$. The other A. terreus isolate PRg4 had an LC50 of $6 \times 10^{7} / \mathrm{ml}$ and the Lecanicillium isolate LIAICRP had $3 \times 10^{11} / \mathrm{ml}$.

Effect of different strains of Entomopathogenic fungi on various developmental stages of Spodoptera litura (Table-2)

\section{Larval Duration and Percent Mortality}

There was only little variation observed between the larval durations of the isolates which ranged from 3.67 to 4.67 days. Among the treatments, L. lecanii isolate LIAICRP (4.67) prolonged the larval period of 4.67 days followed by KoGn5 (4.33 days) which are significantly longer than the untreated control. The percentage of mortality caused by the treatment of Entomopathogenic fungal isolates ranged from 10.33 to 66.67 percent. The isolates, L. lecaniiLlAICRP (66.67), A. terreus ArCo3 (46.67) and $M$. anisopliae KoGn5 (43.33) had significantly higher larval mortality when compared to that of untreated control (10.33). The least mortality among the treatments was observed for $\mathrm{M}$ anisopliae 
isolate MaAICRP isolate (10.33\%) which is same as untreated control. The mortality caused by $M$. anisopliae isolates, LaMa1, $\mathrm{PaCo} 4$ and the A. terreus isolate $\mathrm{PRg} 4$ though higher than the control did not show much variation.

\section{Pupation percentage and pupal period}

The mean percentage of pupation of the isolates ranged from 59.70 percent in $M$. anisopliae isolate $\mathrm{PaCo} 4$ to 90 percent in the untreated control. Except PaCo4, all the other isolates showed non-significant difference in percentage of pupation than the control. The pupal period in L. lecanii isolate LlAICRP was 7.67 days and A. terreus isolates $\mathrm{ArCo} 3$ and PRg4 was 7.67 and 8.67 days respectively. There was no significant difference in the mean pupal period between the isolates.

\section{Percentage of Adult emergence and longevity}

No adults emerged from the pupae infected with $M$. anisopliae isolate KoGn5. The percentages of adult emergence of the remaining isolates ranged from 61.67 to $83.33 \%$ compared to that of the control (90\%). Theadult emergence of the larvae treated with A. terreus isolate PRg4 (46.69) and $M$ anisopliae, LaMa1 (52.54) are significantly lower than the control. A wide variation was observed among the isolates in their effect of the longevity of Spodoptera litura adults. The L. lecanii isolate LlAICRP (5 days) significantly reduced the life span of $S$. litura adults compared to the control (10 days).

It was observed that each isolate had a varied effect on the different stages of insect development. For instance, LlAICRP isolate caused high larval mortality among the isolates but had little effect on the pupation and adult emergence percentages. It again reduced the longevity of the adults significantly. $M$. anisopliae isolate $\mathrm{Ma}$ AICRP though was unable to kill the insect larvae, significantly lowered pupal formation and adult emergence.

The isolate, KoGn5 had significant effect on all the developmental stages of the insect pest. It caused 43.33 percent mortality of larvae which was significantly higher than the control mortality. Though there was 83.33 percent pupation in the remaining larvae, none emerged into adults. $M$ anisopliae isolate Ma AICRP had the least virulence among the isolates and its effect on the different stages of development of insect pest was similar to that of untreated control. It showed the least mortality of the S. litura larvae, without any reduction in percent pupation and percent adult emergence which are comparable with the untreated control.

Entomopathogenic fungi have been proven to be effective in controlling different species of Spodoptera both in laboratory bioassay and in field conditions. Vinayagamoorthi et al. (2011) tested the efficacy of three local isolates of $B$. bassiana on the larvae of $S$. litura and found isolate $\mathrm{Bb}_{10}$ to be most virulent in terms of percent mortality, LC50 and LT50.

In another study, they also tested the potential of three isolates of $M$. anisopliae against $S$. litura and Euproctis fraterna (Castor hairy caterpillar) and noted that $\mathrm{Ma} 2$ isolate was more effective on both the insects than the other two (Vinayagamoorthi et al., 2011). 
Table.1 Evaluation of different isolates of Entomopathogenic Fungi at different concentrations on mortality of S. litura

\begin{tabular}{|c|c|c|c|c|c|c|}
\hline \multirow[t]{2}{*}{ Isolates } & \multicolumn{4}{|c|}{$\begin{array}{c}\text { Percent mortality of } S \text {. litura neonates larvae at } 7 \text { Days } \\
\text { after Treatment }\end{array}$} & \multirow[t]{2}{*}{$\begin{array}{l}\text { LSD } \\
\text { @ } 0.05\end{array}$} & \multirow[t]{2}{*}{ LC50 } \\
\hline & $1 \times 10^{5}$ & $1 \times 10^{6}$ & $1 \times 10^{7}$ & $1 \times 10^{8}$ & & \\
\hline MaAICRP & $\begin{array}{c}27.89^{\mathrm{a}} \pm \\
2.97 \\
(22)\end{array}$ & $\begin{array}{c}33.09^{\mathrm{bc}} \pm \\
4.48 \\
(30)\end{array}$ & $\begin{array}{c}41.54^{\mathrm{abc}} \pm \\
3.16 \\
(44)\end{array}$ & $\begin{array}{c}48.46^{\mathrm{c}} \pm \\
3.16 \\
(56)\end{array}$ & 9.17 & $4 \times 10^{7}$ \\
\hline KoGn5 & $\begin{array}{c}21.69^{b} \pm \\
4.45 \\
(14)\end{array}$ & $\begin{array}{c}41.54^{\mathrm{a}} \pm \\
3.16 \\
(44)\end{array}$ & $\begin{array}{c}48.46^{\mathrm{a}} \pm \\
3.15 \\
(56)\end{array}$ & $\begin{array}{c}60.78^{\mathrm{ab}} \pm \\
3.64 \\
(76)\end{array}$ & 4.88 & $3 \times 10^{6}$ \\
\hline LaMa1 & $\begin{array}{c}21.69^{\mathrm{b}} \pm \\
4.45 \\
(14)\end{array}$ & $\begin{array}{c}27.89^{\mathrm{cd}} \pm \\
2.97 \\
(22)\end{array}$ & $\begin{array}{c}40.33^{\mathrm{abcd}} \\
\pm 4.92 \\
(42)\end{array}$ & $\begin{array}{c}58.37^{\mathrm{ab}} \pm \\
6.94 \\
(72)\end{array}$ & 6.73 & $1 \times 10^{7}$ \\
\hline $\mathrm{PaCo} 4$ & $\begin{array}{l}30.43^{\mathrm{a}} \pm 5.70 \\
\quad(26)\end{array}$ & $\begin{array}{c}36.82^{\mathrm{ab}} \pm \\
3.30 \\
(36)\end{array}$ & $\begin{array}{c}47.31^{\mathrm{ab}} \pm \\
3.16 \\
(54)\end{array}$ & $\begin{array}{c}63.73^{a} \pm \\
5.24 \\
(80)\end{array}$ & 6.02 & $3 \times 10^{6}$ \\
\hline Ll AICRP & $\begin{array}{l}21.68^{\mathrm{b}} \pm 4.45 \\
\quad(14)\end{array}$ & $\begin{array}{l}23.01^{\mathrm{de}} \pm \\
6.70(16)\end{array}$ & $\begin{array}{l}27.17^{\mathrm{f}} \pm \\
9.15(22)\end{array}$ & $\begin{array}{l}31.28^{\mathrm{d}} \pm \\
9.78(28)\end{array}$ & 10.47 & $3 \times 10^{11}$ \\
\hline $\mathrm{ArCo3}$ & $10.82^{\mathrm{c}} \pm 6.85$ & $\begin{array}{l}12.44^{\mathrm{t}} \pm \\
9.62(6)\end{array}$ & $\begin{array}{l}14.98^{\mathrm{g}} \pm \\
10.23(8)\end{array}$ & $\begin{array}{l}19.14^{\mathrm{e}} \pm \\
8.52(12)\end{array}$ & 11.53 & $7 \times 10^{14}$ \\
\hline PRg4 & $\begin{array}{l}17.51^{\mathrm{bc}} \pm \\
7.47(10)\end{array}$ & $\begin{array}{l}20.77^{\mathrm{de}} \pm \\
9.11(14)\end{array}$ & $\begin{array}{l}37.75^{\text {cde }} \pm \\
9.85(38)\end{array}$ & $\begin{array}{l}48.51^{\mathrm{c}} \pm \\
6.65(56)\end{array}$ & 11.22 & $6 \times 10^{7}$ \\
\hline LSD@0.05 & 7.01 & 8.04 & 8.72 & 8.64 & & \\
\hline
\end{tabular}

Values are arc sine transformed mean mortality percentage \pm SD $(\alpha=0.05)$. Values in parentheses are actual mean mortality percentages. The figures denoted by same alphabet in a column are not significantly different by DMRT (p $=0.05)$

$100 \%$ mortality of the $3^{\text {rd }}$ instar larvae of $S$. lituraseven days after treatment was reported for some strains of $M$. anisopliae (Petlumal and Prasertsan, 2012). Freed et al., (2012) tested several isolates of $M$. anisopliae isolated from different crops on Spodopteraexigua and found that the isolates differ in their virulence against the pest. A $M$. anisopliaeisolate FT83 was reported to show $100 \%$ mortality against $S$. exigua larvae (Han et al., 2014).

Shairra and Noah (2014) tested the efficacy of Entomopathogenic fungi and nematodes against $S$. littoralis and found $M$. anisopliae to be very potent both individually and in combination with nematodes. Similarly, in the present study, different isolates of Entomopathogenic fungi differ in their virulence against pest. The highest virulence against the three day old larvae was shown by the M. anisopliae isolate $\mathrm{PaCo} 4$ and $A$. terreus isolate $\mathrm{ArCo} 3$ was the least virulent.

Apart from the fungal strain, the susceptibility of an insect pest depends on various factors like dosage, method of application and the temperature of the environment. Boucias et al., (1988) noted that direct spraying of the conidia on the insect surface enhanced the infectivity of the pathogenic fungi due to the easy cuticular adhesion and germination of the fungal conidia. 
Table.2 Evaluation of different isolates of Entomopathogenic Fungi on growth and development of $3^{\text {rd }}$ instar larvae of $S$. litura

\begin{tabular}{|c|c|c|c|c|c|c|}
\hline Isolates & $\begin{array}{l}\text { Larval duration } \\
\text { (days) }\end{array}$ & $\begin{array}{l}\text { Larval mortality } \\
\text { (per cent) }\end{array}$ & Pupation (per cent) & $\begin{array}{l}\text { Pupal Period } \\
\text { (days) }\end{array}$ & $\begin{array}{l}\text { Adult emergence } \\
\text { (per cent) }\end{array}$ & $\begin{array}{l}\text { Adult longevity } \\
\text { (days) }\end{array}$ \\
\hline MaAICRP & $4.00 \pm 0^{\mathrm{ab}}$ & $\begin{array}{c}14.20^{\mathrm{c}} \pm 7.33 \\
(6.67)\end{array}$ & $\begin{array}{c}55.89^{\mathrm{ab}} \pm 13.11 \\
(67.10)\end{array}$ & $8.33^{\mathrm{a}} \pm 1.15$ & $\begin{array}{c}56.92^{\mathrm{abc}} \pm 30.47 \\
(61.67)\end{array}$ & $8.67^{\mathrm{abcd}} \pm 2.89$ \\
\hline Ma KoGn5 & $4.33 \pm 0.58^{b c}$ & $\begin{array}{c}36.14^{\mathrm{abc}} \pm 19.34 \\
(36.67)\end{array}$ & $\begin{array}{c}75^{\mathrm{ab}} \pm 25.98 \\
(83.33)\end{array}$ & $\begin{array}{l}\text { Pupae failed to } \\
\text { emerge }\end{array}$ & $\begin{array}{c}\text { Pupae failed to } \\
\text { emerge }\end{array}$ & $\begin{array}{c}\text { Pupae failed to } \\
\text { emerge }\end{array}$ \\
\hline Ma LaMa1 & $4.00 \pm 0^{\mathrm{ab}}$ & $\begin{array}{c}21.83^{b c} \pm 14.33 \\
(16.67)\end{array}$ & $\begin{array}{c}76.36^{\mathrm{ab}} \pm 23.62 \\
(85.70)\end{array}$ & $8.00^{\mathrm{a}} \pm 0$ & $\begin{array}{c}52.54^{\mathrm{ab}} \pm 10.25 \\
(62.60)\end{array}$ & $9.00^{\text {bcde }} \pm 2.65$ \\
\hline $\mathrm{Ma} \mathrm{PaCo} 4$ & $4.00 \pm 0^{\mathrm{ab}}$ & $\begin{array}{c}26.07^{\mathrm{bc}} \pm 7.40 \\
\text { (20) }\end{array}$ & $\begin{array}{c}50.64^{\mathrm{a}} \pm 5.04 \\
(59.70)\end{array}$ & $8.00^{\mathrm{a}} \pm 0$ & $\begin{array}{c}66.92^{\mathrm{abc}} \pm 20.51 \\
(78.33)\end{array}$ & $7.33^{\mathrm{ab}} \pm 0.58$ \\
\hline Ll AICRP & $4.67 \pm 0.58^{c}$ & $\begin{array}{c}51.14^{\mathrm{a}} \pm 10.64 \\
(60)\end{array}$ & $\begin{array}{c}70^{\mathrm{ab}} \pm 34.64 \\
(75.00)\end{array}$ & $7.67^{a} \pm 0.58$ & $\begin{array}{c}75^{\mathrm{abc}} \pm 25.98 \\
(83.33)\end{array}$ & $5.00^{\mathrm{a}} \pm 2.65$ \\
\hline Vl ArCo3 & $4.00 \pm 0^{\mathrm{ab}}$ & $\begin{array}{c}38.85^{\mathrm{ab}} \pm 21.29 \\
(40)\end{array}$ & $\begin{array}{c}75^{\mathrm{ab}} \pm 25.98 \\
(83.33)\end{array}$ & $7.67^{\mathrm{a}} \pm 0.58$ & $\begin{array}{c}68.44^{\mathrm{abc}} \pm 18.67 \\
(80.93)\end{array}$ & $7.67^{\mathrm{abc}} \pm 0.58$ \\
\hline Vl PRg4 & $4.00 \pm 0^{\mathrm{ab}}$ & $\begin{array}{c}32.71^{\mathrm{abc}} \pm 10.64 \\
(30)\end{array}$ & $\begin{array}{c}77.41^{\mathrm{ab}} \pm 21.80 \\
(87.50)\end{array}$ & $8.67^{\mathrm{a}} \pm 0.58$ & $\begin{array}{c}46.69^{\mathrm{a}} \pm 11.55 \\
(52.60)\end{array}$ & $7.33^{\mathrm{ab}} \pm 3.51$ \\
\hline $\begin{array}{c}\text { Control } \\
\text { T8 } \\
\end{array}$ & $3.67 \pm 0.58^{\mathrm{a}}$ & -- & $\begin{array}{c}90^{\mathrm{b}} \pm 0 \\
(100.00)\end{array}$ & $8.00^{\mathrm{a}} \pm 0$ & $\begin{array}{c}90^{c} \pm 0 \\
(100.00)\end{array}$ & $10.00^{\text {bcde }} \pm 0$ \\
\hline LSD@ 5\% & 0.61 & 24.48 & 37.63 & 1.01 & 33.82 & 3.93 \\
\hline
\end{tabular}

The values in percentages are arc sine transformed \pm SD.

Values in parentheses are means of actual percentage.

The figures denoted by same alphabet in a column are not significantly different by DMRT $(\alpha=0.05)$ 
The mode of infection employed in the present study though showed less mortality percentage of the insect larvae compared to some other reports closely mimics the mode of application in the field and thus is more of practical use.

Vinayagamoorthi et al., (2011) noted that the mortality of the pest increases with the increase in the conidial concentration. Results in the present study also indicate that the mortality percentage of the $S$. litura larvae increased with the increase in the conidial concentration of the isolates. The decrease in the mortality percentage from the $1^{\text {st }}$ instar larvae to the $3^{\text {rd }}$ instar larvae in the present study is in agreement with findings in the previous studies that the susceptibility of an insect pest to the pathogenic fungi decreases with the increase in the age of the larvae (Osborne et al., 1990). The body size and the increased immunity of the higher instar larvae may affect the infection, multiplication and mycosis of the fungi on the insect.

The unique mode of action of Entomopathogenic fungi involving contact and penetration of the fungal conidia to the host cuticle makes them to be able to infect sucking pests, such as aphids and mosquitoes (Wang and Feng, 2014) as well as the nonfeeding stages of the insect pests (Anand et al., 2009). Anand et al., (2009) treated the pupae of Spodoptera litura (Fab.), (Lepidoptera: Noctuidae) with conidial suspensions of different species of entomopathogenic fungi and found $M$ anisopliae to be most virulent among them followed by L. muscarium. Asi et al., (2013) studied the effect of different Entomopathogenic fungi against all life stages of Spodoptera litura and found that while pupae were less susceptible to fungal infection, eggs and larvae are more susceptible to the fungal infection. In the present study, a laboratory bioassay was carried out on the $3^{\text {rd }}$ instar larvae to evaluate the effect of fungal infection on the different developmental stages of the $S$. litura such as mortality, larval duration, percentage and duration of pupae, adult emergence percentage and longevity. It was found that the isolates increased the larval duration and decreased the longevity of the adults of the insect pest but did not affect the pupal period. Similar result was reported by Malarvannan et al., (2010) but Hafez et al., (1997) reported prolonged pupal duration in Phthorimaea operculella treated with $B$. bassiana.

It was found that each isolate in the study affected the stages of insect development differently. For instance, while L. lecanii isolate V1 AICRP showed prolonged larval duration, highest mortality and lowest adult longevity, M. anisopliae isolate $\mathrm{PaCo} 4$ had the lowest percent pupation. It was also found that all the pupae of the KoGn5 treated larvae failed to emerge into adults. The metamorphosis of an insect is known to be greatly influenced by the juvenile hormone titre as its changes can cause disturbances in the storage proteins and fats necessary for moulting (Palli and Locke, 1987; Koul and Isman, 1991). Larval-Pupal intermediates like deformed pupae such as those reported by Malarnannan et al., (2010) were also seen in the present study. Asi et al., (2013) noted that the susceptibility of an insect pest to the fungal pathogen decrease as the larvae grows. However, in the present study, it was interesting to note that L. lecanii isolate $\mathrm{Vl}$ AICRP which had only 28 percent mortality against $1^{\text {st }}$ instar larvae of S. litura at $10^{8}$ conidia $/ \mathrm{ml}$ had a mortality percentage of $66.67 \%$ on the $3^{\text {rd }}$ instar larvae even at a lower concentration of $10^{6}$ conidia $/ \mathrm{ml}$.

Eventhough, Aphanoascus spp are not known to be Entomopathogenic in nature, it was found in the present study that A. terreus isolate $\mathrm{PRg} 4$ caused mortality of $S$. litura 
larvae similar to that of the AICRP strain of $M$. anisopliae in the laboratory conditions. Aphanoa scusterreus belongs to the family onygenaceae of Ascocmycetes. Many species in the genus are known to be keratinolytic saprotroph mostly found in keratin rich soils. Chrysosporium, a teleomorph of the Aphanoascus is reported to control mosquitos (Preeti and Prakash, 2010). Entomopathogenic fungi are important components of Biological control of insect pests.Wide variations occur in the effectivity of different strains and selection of virulent ones is critical in their success. Few isolates in the present study were promising candidates for further investigation on their field efficacy before their successful use in agriculture. Moreover, the efficient mass multiplication of the virulent isolates also plays a key role in their employability as Mycopesticides

\section{Acknowledgements}

The authors are thankful to NBAIR, Bengaluru for kindly providing the eggs of $S$. litura for the study.

\section{References}

Abbott WS. 1925. A method of computing the effectiveness of an insecticide. J. econ.Entomol. 18: 265-267.

Alavo TB. 2015. The insect pathogenic fungus Verticillium lecanii (zimm.) Viegas and its use for pests control: a review. JExpBiol, 3.

Anand R, Birendra P, and Bhupendra NT. 2009.Relative susceptibility of Spodoptera litura pupae to selected entomopathogenic fungi. BioControl. 54:85-92.

Armes, Nigel J., et al., 1997. Status of insecticide resistance in Spodoptera litura in Andhra Pradesh, India. Pest Sci. 50: 240-248.
Asi MR, Bashir MH, Afzal M, Zia K, and Akram M. 2013. Potential of entomopathogenic fungi for biocontrol of Spodoptera litura fabricius (lepidoptera: noctuidae). J Anim Plant Sci. 23:913-918.

Askary H, Carriere Y, Belanger RRand Brodeur J. 1998.Pathogenicity of the fungus Verticillium lecanii to aphids and powdery mildew. Biocontrol SciTechn. 8: 23-32.

Boucias DG, Pendland JCand Latge JP. 1988. Nonspecific factors involved in attachment of Entomopathogenic Deuteromycetes to host insect cuticle. Appl Environ Microb. 54: 17951805.

Brown ES and Dewhurst CF. 1975. The genus Spodoptera (Lepidoptera:Noctuidae) in Africa and the Near East. BEntomol Res.65: 221-262.

Chandra Teja,KNP,and Rahman SJ. 2016. Characterisation and evaluationof Metarhizium anisopliae (Metsch.) Sorokin strains for their temperature tolerance, Mycology.

Cho EM, Liu L, Farmerie Wand Keyhani NO. 2006. EST analysis of cDNA libraries from the entomopathogenic fungus Beauveria (Cordyceps) bassiana. I. Evidence for stage-specific gene expression in aerial conidia, in vitro blastospores and submerged conidia. Microbiology. 152: 2843-2854.

deFaria MRand Wraight SP. 2007. Mycoinsecticides and mycoacaricides: a comprehensive list with worldwide coverage and international classification of formulation types. Biol Control. 43: 237-256.

Feng MG, Poprawski TJand Khachatourians GG. 1994. Production, formulation and application of the entomopathogenic fungus Beauveriabassiana for insect control: current status. Biocontrol SciTechn 4: 3-34. 
Ferron P. 1978.Biological control of insect pests by entomogenous fungi. Annu RevEntomol. 23: 409-442.

Freed S, Saleem MA, Khan MBand Naeem M. 2012. Prevalence and effectiveness of Metarhizium anisopliae against Spodopteraexigua (Lepidoptera: Noctuidae) in southern Punjab, Pakistan. Pak J Zool. 44:753-758.

Hafez M, Zaki FN, Moursy Aand Sabbour M. 1997.Biological effects of the entomopathogenic fungus, Beauveria bassiana on the potato tuber moth Phthorimaea operculella. Anzeigerfür Schädlingskunde, Pflanzenschutz, Umweltschutz. 70:158-159.

Han JH, Jin BR, Kim JJand Lee SY. 2014. Virulence of Entomopathogenic Fungi Metarhizium anisopliae and Paecilomyces umosoroseus for the Microbial Control of Spodopteraexigua. Mycobiology. 42: 385-390.

Holloway and Jeremy D. 1989.The moths of Borneo: family Noctuidae, trifine subfamilies: Noctuinae, Heliothinae, Hadeninae,Acronictinae, Amphipyrinae, Agaristinae. Malayan Nat J. 42: 57-228.

Koul Oand Isman MB. 1991. Effects of azadirachtin on the dietary utilization and development of the variegated cutworm Peridromasaucia. J Insect Physiol. 37:591-598.

Malarvannan S, Murali PD, Shanthakumar SP, Prabavathy VRand Nair S. 2010. Laboratory evaluation of the entomopathogenic fungi, Beauveriabassiana against the tobacco caterpillar, Spodoptera lituraFabricius (Noctuidae: Lepidoptera). J Biopesticides. 3:126-131.

Moorthi PV, Balasubramanian Cand Kubendran T. 2011.Efficacy of local isolates of Beauveriabassiana against Spodoptera litura (F.) (Lepidoptera: Noctuidae). JBiol Control. 25: 22-25.
Núñezdel Prado E, Iannacone Jand Gómez H. 2008. Efecto de Dos Hongos Entomopatógenosen el Control de Aleurodicuscocois (Curtis, 1846) (Hemiptera: Aleyrodidae). Chil JAgrRes. 68: 21-30.

Osborne LS, Storey GK, McCoy CW, Walter JF. 1990. Potential for controlling the sweetpotato whitefly, Bemisiatabaci, with the fungus, Paecilomyces fumosoroseus. In: Proceedings and Abstracts, Vth International Colloquium on Invertebrate Pathology and Microbial Control. Society for Invertebrate Pathology, Adelaide, Australia.386-390.

Palli SRand Locke M. 1987. The synthesis of hemolymph proteins by the larval epidermis of an insect Calpodesethlius (Lepidoptera:

Hesperiidae). InsectBiochem. 17: 711722.

Petlamul WandPrasertsan P. 2012. Evaluation of strains of Metarhizium anisopliae and Beauveriabassiana against Spodoptera litura on the basis of their virulence, germination rate, conidia production, radial growth and enzyme activity. Mycobiology. 40: 111-116.

Shairra SAand Noah GM. 2014.Efficacy of Entomopathogenic Nematodes and Fungi as Biological Control Agents against the Cotton Leaf Worm, Spodoptera littoralis (Boisd.) (Lepidoptera: Noctuidae). Egypt J Biol Pest Control. 24: 247.

Shinya R, Aiuchi D, Kushida A, Tani M, Kuramochi Kand Koike $M$. 2008. Effects of fungal culture filtrates of Verticilliumlecanii (Lecanicillium spp.) hybrid strains on Heteroderaglycines eggs and juveniles. J InvertebrPathol. 97: 291297.

vanLenteren, JC. 2007. Biological control for insect pests in greenhouses: an 
unexpected success. Biological control: a global perspective. $\mathrm{CAB}$ Int. Wallingford.pp.105-117.

Verma P and Prakash S. 2010.Efficacy of Chrysosporium tropicum metabolite against mixed population of adult mosquito (Culex quinquefasciatus, Anopheles stephensii, and Aedes aegypti) after purification with flash chromatography. Parasitol.

Res. 107:163-166.

Vestergaard S, Gillespie AT, Butt TM, Schreiter Gand Eilenberg J. 1995.Pathogenicityof the hyphomycete fungi Verticilliumlecanii and Metarhizium anisopliae to the western flower thrips, Frankliniella occidentalis. Biocontrol SciTechn. 5: 185-192.

Wang Cand Feng MG. 2014.Advances in fundamental and applied studies in China of fungal biocontrol agents for use against arthropod pests. Biol Control. 68:129-135.

Wang L, Huang J, You M, Guan Xand Liu B. 2007. Toxicity and feeding deterrence of crude toxin extracts of Lecanicillium (Verticillium) lecanii (Hyphomycetes) against sweet potato whitefly, Bemisiatabaci (Homoptera: Aleyrodidae). Pest Manag Sci. 63: 381387.

White TJ, Bruns T, Lee S, Taylor JW. 1990. Amplification anddirect sequencing of fungal ribosomal RNA genes for phylogenetics.In: Innis MA, Gelfand DH, Sninsky JJ, White TJ,editors. PCR protocols: a guide to methods and applications.San Diego (CA): Academic Press. p. $315-322$.

\section{How to cite this article:}

Chandra Teja. K. N. P. and Rahman. S. J. 2020. Virulence of Local isolates of Entomopathogenic Fungi on the common agricultural pest Spodoptera litura (Fabricius) Lepidoptera:Noctuidae. Int.J.Curr.Microbiol.App.Sci. 9(02): 2768-2778. doi: https://doi.org/10.20546/ijcmas.2020.902.315 